\title{
Menanamkan Budaya Literasi pada Anak Usia Dini Melalui Dongeng
}

\author{
Winda Dwi Hudhana ${ }^{1}$, Ariyana ${ }^{2}$ \\ Universitas Muhammadiyah Tangerang \\ Windhana89@gmail.com
}

\begin{abstract}
Abstrak
Budaya literasi menjadi sesuatu yang urgen ketika membahas mengenai wawasan dan pengetahuan. Pada zaman globalisasi saat ini, banyak terjadi degradasi wawasan dan pengetahuan yang diakibatkan kurangnya budaya literasi oleh masyarakat. Budaya literasi tidak ditanam sejak kecil sehingga menurunkan minat baca pada masyarakat. Kemajuan dan perkembangan teknologi menjadi faktor utama yang mempengaruhi budaya literasi. Banyaknya alat yang memudahkan pekerjaan manusia dan yang mengefisiensi waktu membuat masyarakat terlena sehingga kebutuhan literasi menurun. Berbeda dengan zaman dahulu, bahwa para masyarakat dahulu memahami pentingnya literasi. Banyaknya kaya-karya berkaitan dengan pengetahuan tercipta, contohnya dongeng. Karya sastra berupa dongeng merupakan wujud warisan budaya literasi nenek moyang. Mereka menciptakan dongeng sebagai upaya untuk membudayakan gerakan literasi.
\end{abstract}

Kata Kunci : Literasi, Anak Usia Dini, Dongeng,

\section{A. Pendahuluan}

Beberapa penelitian mengenai budaya literasi beberapa tahun lampau membuktikan bahwa budaya literasi di Indonesia sangat rendah. Menurut UNESCO bahwa budaya literasi bangsa Indonesia menempati urutan ke 60 dari 61 negara di dunia. Selain itu, menurut data dari UNESCO bahwa budaya literasi di Indonesia hanya mencapai $1 \%$ yang menyukai kegiatan membaca dan 99\% tidak menyukai kegiatan membaca. Budaya literasi di masyarakat khususnya di kalangan anak-anak masih minim, masih banyak anak yang hanya membaca satu buku bahkan tidak sama sekali dalam satu bulan bahkan dalam satu tahun.

Faktor penyebab rendahnya budaya literasi dikalangan masyarakat Indonesia sangat banyak. Faktor tersebut dibedakan menjadi faktor intern individu dan ekstern individu. Faktor intern individu yaitu tidak memiliki waktu luang, lebih menyenangkan gatged daripada buku, tidak tertarik pada buku, masih minimnya kesadaran pentingnya literasi, dan sebagainya. 
Sedangkan faktor ekstern individu yaitu fasilitas buku yang kurang memadahi, harga buku relatif mahal, tidak ada dukungan dari orang tua, tidak adanya kebiasaan membaca di lingkungan sekitar, dan sebagainya.

Budaya literasi perlu adanya pembiasaan dan kesadaran di lingkungan masyarakat. Para orang tua seharusnya mampu membimbing anak-anaknya sejak dini untuk gemar membaca. Usia anak dini merupakan usia emas yang mana masa tersebut merupakan masa para anak memiliki ingatan panjang. Usia dini adalah kesempatan emas anak dalam mempelajari sesuatu atau dapat disebut dengan golden age (Sulistyani, 2015:14). Anak pada usia ini memiliki ketertarikan yang sangat pada lingkungan.

Menurut Locke bahwa manusia berkembang sesuai dengan tempramen masing-masing individu dan lingkungan yang mempengaruhi pembentukan pemikiran seseorang (Khotimah, 2015:62). Proses perkembangan seorang anak sebenarnya terjadi dalam masa bayi yang mana pada masa itu, bayi dapat dibentuk dan dipengaruhi sesuai keinginan orang tua dan lingkungan sekitar. Apabila seorang anak yang dibesakan dalam keluarga dan lingkungan yang gemar membaca, maka dengan sendirinya anak tersebut terbentuk menjadi generasi yang menjunjung tinggi gerakan literasi. Untuk itu, anak usia dini sangat tepat apabila orang tua mampu menerapkan gerakan literasi di lingkungan keluarga maupun sekitar.

Gerakan literasi mampu dibangkitkan dengan kegiatan mendongeng. Apabila anak diajarkan dongeng oleh orang tua dari usia dini, maka ia akan terbiasa dengan karya sastra. Sebelum pembahasan lebih jauh mengenai dongeng, perlu diketahui hal-hal berkaitan dengan dongeng. Dongeng adalah genre cerita anak yang bersifat fiktif-imajinatif (Kurniawan, 2016:4). Dongeng merupakan warisan budaya yang diturunkan sebagai media dalam memberikan pembelajaran mengenai pengalaman dan pengetahuan mengenai kehidupan. Kegiatan membaca dongeng merupakan upaya orang tua dalam membantu anak usia dini dalam mengembangkan potensi diri dan mengajarkan pengalaman kehidupan karena pada masa itu anak berkembang dengan cara imitasi (Hudhana dan Fadhillah, 2018:100).

Dongeng memberikan manfaat sangat banyak bagi anak-anak usia dini, karena dongeng bersifat menghibur dan mendidik. Kosep ini berkaitan dengan tujuan dongeng yaitu memberikan pendidikan moral dengan cara yang menyenangkan. Sifat menghibur berkaitan dengan hal-hal 
yang mampu memberikan sensasi kesenangan, kesedihan, ketakutan, kegelisahan dan sebagainya. Sedangkan sifat mendidik berkaitan dengan pendidikan moral yang dapat diajarkan berkaitan dengan kandungan makna dongeng. Maka, orang tua sangat diajurkan untuk menumbuhkan gerakan literasi di keluarga melalui dongeng.

\section{B. Pembahasan}

Dongeng adalah salah satu jenis sastra anak yang sangat disukai anak-anak karena mengandung karakter-karakter yang disukai anak. Karakter yang terdapat dalam dongeng disajikan secara imajinatif dan kreatif oleh pengarang. Karakter ini biasanya berkaitan dengan hal-hal yang berada diluar dunia nyata, misalnya putri, peri, pangeran, raja, kurcaci, dan sebagainya. Sebuah dongeng yang baik harus mampu menghadirkan karakter yang kuat dan mengajarkan kebaikan. Maka, anak-anak mampu belajar dari karakter yang ditampilkan.

Berlandaskan asumsi tersebut, gerakan literasi dapat dilakukan menggunakan memberikan buku-buku dongeng maupun kegiatan mendongeng yang dilakukan di rumah. Maka, perlu diketahui cara memilih dongeng yang baik antara lain:

1. Mengetahui kebutuhan dan minat anak terhadap dongeng. Setiap anak memiliki kebutuhan mengenai karakter yang akan diajarkan kepada anak. Pemberian dongeng kepada anak juga mempertimbangkan minat anak terhadap dongeng. Apabila kita memaksakan dongeng yang tidak disukai anak maka anak akan menolak dan merasa terpaksa.

2. Memberikan buku dongeng kepada anak harus memperhatikan usia anak. Di dalam memilih buku dongeng haruslah disesuaikan dengan perkembangan usia anak. Apabila anak tersebut masih dalam usia dini maka buku dongeng yang cocok yaitu buku dongeng dengan gambar-gambar yang lebih banyak daripada buku dongeng anak-anak usia Sekolah Dasar.

3. Mempertimbangkan kualitas buku dongeng. Pengajaran karakter dalam dongeng merupakan tujuan utama orang tua dalam memberikan buku dongeng kepada anak. Maka, kualitas buku harus dipertimbangkan sehingga karakter-karakter dalam dongeng dapat ditiru dengan baik oleh anak-anak. 
Sebaiknya para orang tua tidak semata-mata memberikan buku dongeng kepada anak, namun orang tua berperan serta dalam kegiatan literasi. Orang tua dapat melakukan kegiatan mendongeng bersama dengan anak-anak. Kegiatan mendongeng bersama ini memiliki banyak keuntungan yakni: 1) mempererat hubungan anak dengan orang tua, 2) orang tua dapat mengawasi anak ketika mendongeng sehingga dapat meminimalisasi hal-hal negatif yang terdapat dalam dongeng, 3) para orang tua dapat memberikan pemahaman kepada anak apabila di dalam dongeng terdapat hal-hal yang kurang dipahami anak, dan 4) Bahasa Ibu dapat dikuasai dengan baik oleh anak.

Kegiatan mendongeng juga dapat digunakan sebagai penguasaan bahasa Ibu. Oleh karena, bahasa Ibu merupakan bahasa yang digunakan oleh anak dan ibunya dalam bekomunikasi sehingga penguasaan bahasa Ibu diwajibkan kepada anak. Selain itu, orang tua juga mampu mengembangkan kosa kata bahasa Ibu dengan kegiatan mendongeng. Pengenalan bahasa Ibu memberikan dampak baik bagi anak yakni: 1) bahasa Ibu tidak akan punah, 2) bahasa Ibu membangkitkan keakraban dengan anak, 3) dapat menanamkan pendidikan karakter kepada anak (Kurniawan, 2017:115-116).

Pelaksanaan kegiatan mendongeng bagi orang tua harus direncanakan dengan matang sehingga mampu mempersembahkan dongeng yang baik dan bermutu. Maka diperlukan upayaupaya berikut:

\section{Tentukan Tujuan Kegiatan Mendongeng}

Tujuan dalam segala kegiatan merupakan hal yang sangat penting, tanpa kejelasan tujuan maka suatu kegiatan akan menjadi kesia-siaan. Untuk itu, tujuan dalam kegiatan mendongeng harus jelas untuk apa kegiatan mendongeng dilaksanakan. Penentuan tujuan mendongeng harus sesuai dengan usia anak, kebutuhan anak, minat anak dan keadaan anak. Apabila salah satu faktor penentu tujuan tidak terpenuhi maka kegiatan mendongeng tidak dapat terlaksana dengan baik.

2. Tentukan Materi untuk Kegiatan Mendongeng

Setelah tujuan ditentukan, langkah selanjutnya yaitu menentukan materi untuk mendongeng. Pilihlah materi dongeng yang sesuai dengan kebutuhan anak, minat anak, tujuan mendongeng. Selain itu, pilihlan materi dongeng yang berkaitan dengan pembelajaran karakter yang akan diajarkan, misalnya apabila kita akan mengajarkan 
mengenai kejujuran, kita dapat menggunakan dongeng yang bertema kejujuran dan sebagainya.

3. Tentukan Media untuk Mendongeng

Media dalam mengongeng sangatlah penting, karena dongeng akan menarik apabila orang tua mampu menghidupkan dongeng melalui media. Media dongeng bermacam-macam misalnya boneka, wayang, gambar dan sebagainya. Media dongeng dapat diciptakan sendiri oleh orang tua, misalnya dengan membuat wayang yang dikreasikan dari gambar-gambar bekasi dikoran dan diberi penyangga. Semakin menarik media dongeng maka kegiatan mendongeng akan lebih menarik dan menyenangkan.

4. Pelaksanaan Kegiatan Mendongeng

Kegiatan dongeng dapat dilakukan dengan cara mendongeng melalui teks, hafalan dan improvisasi. Kegiatan mendongeng melalui teks dilakukan orang tua apabila mereka tidak hafal isi dongeng. Kegiatan mendongeng melalui hafalan yaitu uupaya orang tua dalam mendongeng dengan menghafal teks dongeng. Selain itu, kegiatan mendongeng dengan improvisasi yaitu orang tua memvariasikan dongeng dengan bahasa mereka sendiri. Beberapa metode dongeng tersebut yang paling efektif yaitu dengan improvisasi. Oleh karena, para orang tua mampu dengan leluasa melakukan kegiatan dongeng.

\section{Umpan Balik Kegiatan Mendongeng}

Kegiatan umpan balik diperlukan untuk mengetahui sejauh mana pemahaman anak terhadap dongeng yang telah diperdengarkan. Orang tua harus menyiapkan beberapa pertanyaan yang berkaitan dengan isi dongeng. Apabila anak mampu menjawab pertanyaan orang tua, maka anak tersebut telah memahami isi dongeng.

\section{Simpulan}

Gerakan literasi diharapkan dapat ditanamkan sejak usia dini dengan menggunakan karya sastra. Penggunaan karya sastra misalnya dongeng, karena dongeng mengandung imajinasi dan kreatifitas cerita yang memiliki daya tarik yang tinggi. Peran serta orang tua juga dapat mempengaruhi lancarnya gerakan literasi anak, maka orang tua diharapkan mampu mengarahkkan anak dalam membaca dongeng. Peran orang tua berkaitan dalam pemilihan buku 
dongeng yang baik dan berkualitas. Selain itu, peran orang tua berkaitan juga dalam kegiatan mendongeng sehingga gerakan literasi anak dapat berjalan dengan baik dan lancar.

\section{Daftar Pustaka}

Hudhana, Winda Dwi dan Dilla Fadhillah. 2018. Menumbuhkan Kecerdasan Bahasa dan Karakter Bangsa Melalui Aktivitas Mendongeng pada Siswa Sekolah Dasar. Jurnal Lingua Rima. Fakultas Keguruan dan Ilmu Pendidikan Universitas Muhammadiyah Tangerang. Volume 7 No 1 Januari 2018 PP 99-105

Khotimah, Khusnul. 2015. Peran Orang Tua dalam Mengembangkan Perilaku Sosial pada Anak Usia Dini. Jurnal Insania Jurnal Pendidikan. Fakultas Tarbiyah dan Ilmu Keguaran. Institut Agama Islam Negeri Purwokerto. Volum 20 No 1 Januari-Juni 2015 PP 59-78

Kurniawan, Heru. 2016. Kreatif Mendongeng untuk Kecerdasan Jamak Anak. Jakarta: Kencana 2017. Solutif Parenting: 33 Cara Praktis untuk Mewujudkan Anak Cerdas, Kreatif dan Berkarakter. Jakarta: PT Elex Media Komputindo Kompas Gramedia

Sulistyani, Anggraeni Mashinta. 2015. Pengenalan Sains bagi Anak Usia Dini Menggunakan Metode Permainan. Jurnal Insania: Jurnal Pendidikan. Fakultas Tarbiyah dan Ilmu Keguaran. Institut Agama Islam Negeri Purwokerto. Volum 20 No 1 Januari-Juni 2015 PP $13-27$ 